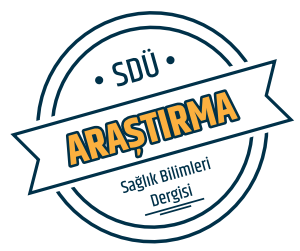

\title{
Asemptomatik Tam Gömük Alt Yirmi Yaş Dişlerinin Foliküllerinde Ki-67 ve p53 Ekspresyonunun Değerlendirilmesi
}

\section{The Evaluation Ki-67 and p53 Expressions in The Asymptomatic Impacted Third Molar Follicles}

\author{
Ender Burhanoğlu', Müge Çına Aksoy², Pınar Aslan Koşar³ \\ ${ }^{1}$ Serbest Diş Hekimi, Balıkesir, Türkiye. \\ ${ }^{2}$ Süleyman Demirel Üniversitesi, Diş Hekimliği Fakültesi, Ağız Diş ve Çene Cerrahisi AD., Isparta, Türkiye. \\ ${ }^{3}$ Süleyman Demirel Üniversitesi Tıp Fakültesi, Tıbbi Biyoloji AD., Isparta, Türkiye.
}

\section{Özet}

Amaç: Gömük diş çekimi, özellikle en sık gömük kalan dişler olan alt yirmi yaş dişlerinin çekimi, en çok gerçekleştirilen oral cerrahi işlemdir. Asemptomatik tam gömük alt yirmi yaş dişlerinin çekimi konusunda net bir görüş birliğine varılamamıştır. Ki-67, farklı hücre populasyonlarının büyüme hızını yani proliferasyon indeksini belirlemede kullanılmaktadır. p53 ise tümör baskılayıcı bir proteindir. Sağlıklı dokuların tersine, tümör hücrelerinde p53 proteininin ekspresyonu artmaktadır. $\mathrm{Bu}$ çalışmanın amacı, sigara kullanan ve kullanmayan bireylerin, asemptomatik tam gömük alt yirmi yaş dişlerinin perikoronal foliküllerinde p53 ve Ki-67 proteinlerinin ekspresyonlarının karşılaştırılmasıdır. Materyal-Method: Çalışmaya 50 sigara kullanan, 50 sigara kullanmayan 100 hastadan, asemptomatik tam gömük alt yirmi yaş dişlerinin perikoronal folikülleri dahil edilmiştir. Dokularda, p53 ve Ki-67 antikorları ile immunohistokimyasal boyama yapılarak immünhistokimyasal olarak, hücre çekirdeği boyanan hücre sayısı ve boyanma yoğunlukları skorlanarak değerlendirilmiştir.

Bulgular: Çalışmamızda, sigara kullanan ve kullanmayan hastaların perikoronal foliküllerinde, Ki-67 ve p53 proteinlerinin boyanması "negatif" olarak bulundu.

Sonuç: Çalışmamızın sonuçlarına göre, her ne kadar sigaranın genel sağlık açısından bir risk faktörü oluşturduğu biliniyor olsa da, asemptomatik tam gömük dişlerin patolojik dönüşüm riskini arttırdığına dair net bir kanıt bulunamamıştır. Gömük alt yirmi yaş dişlerinin çekimine, detaylı klinik ve radyografik muayene ile birlikte hastanın sosyokültürel düzeyi göz önünde bulundurularak, karar verilmesi uygun bir seçenek olabilir.

Anahtar kelimeler: Dental folikül, immunohistokimya, Ki-67, p53, sigara

\begin{abstract}
Objective: Extraction of impacted tooth, especially the lower third molars which have highest prevalance of impaction, is the most common surgical procedure performed in oral surgery. There is still an ongoing debate about the extraction of asymptomatic fully impacted lower third molars. Ki-67 is a proliferation marker protein used to evaluate the proliferative index of various cell populations. p53 is a tumor suppressor protein. Unlike healthy cells, there is an increased expression of p53 in tumor cells. The aim of this study was to evaluate the Ki-67 and p53 protein expression in dental follicles of asymptomatic fully impacted lower third molar teeth of smoking and non smoking patients.
\end{abstract}

Material-Method: Study population comprised 50 smoking and 50 non smoking patients. Dental follicles of asymptomatic fully impacted lower third molar teeth attained from the patients were stained immunohistochemically with Ki-67 and p53 antibodies and staining intensities and patterns of the specimens were evaluated.

Results: In our study, Ki-67 and p53 stainings were found to be "negative" in both the study and the control group. Conclusions: Although it is known that smoking has adverse affects on health, in our study, we were unable to find any finding confirming that smoking habit increases pathological transformation risk of asymptomatic fully impacted teeth. Therefore, when dealing with these teeth, detailed clinical and radiographical examinations with sociocultural aspects taken into consideration, monitorization can be the treatment of choice.

Keywords: Dental follicle, immunohistochemistry, Ki-67, p53, smoking

görüntü veren gömük yirmi yaş dişlerinin çekim kararı ile ilgili tam bir fikir birliğine varılamamıştır. Asemptomatik ve radyografik olarak sağlıklı görünen gömük yirmi yaş dişlerinin foliküllerinde yapılan histolojik incelemelerde tespit edilen patolojik değişiklikler profilaktik çekimin tercih edilmesi gerektiği şeklinde yorumlanmaktadır (3).

Sigara kullanımı en sık akciğer kanserine neden olmakla beraber, baş-boyun bölgesi kanserlerinin en büyük etkenlerinden biridir ve erkeklerdeki baş-boyun bölgesi 
kanserlerinin \%23'ünden sorumlu tutulmaktadır (4). Sigara içinde yer alan kanserojen maddelere tekrarlayan şekilde maruz kalma, oral kavitenin çok katlı yassı epitel hücrelerinde proliferatif değişikliklere yol açmaktadır (4).

Dokuların kansere yatkınlığını ve kanserin prognozunu değerlendirmek için yapılan çalışmalarda Ki-67 ve p53 proteinlerinin kanserle ilişkili olabileceği rapor edilmiştir (5). Ki-67, hücre proliferasyonu için hayati öneme sahip bir proteindir ancak etki mekanizması hakkında net bir bilgi bulunmamaktadır (6). Ki-67 proteinin dokulardaki ekspresyonu, patolojide tümör hücrelerin büyüme fraksiyonunu ölçmek için hücre çoğalması belirleyicisi olarak kullanılır (5).

p53 proteini normal koşullar altında dokularda çok az miktarda bulunur. Normal hücre siklusunda herhangi bir değişiklik yaratacak veya hücrenin kanserli hücreye dönüşmesine yol açacak bir mutasyonu tetikleyebilecek hücresel stress varlığında aktive olur. Aktive olan p53 proteini hücre siklusunu durdurarak veya apoptozu başlatarak hasarlı hücrelerin yok edilmesini sağlar (7).

$\mathrm{Bu}$ çalışmanın amacı, radyografik olarak sağlıklı ve asemptomatik olan gömük alt yirmi yaş dişlerinden elde edilen perikoronal foliküllerde, Ki-67 ve p53 proteinlerinin immunohistokimyasal boyanmaları ve dağılımının tespit edilmesi ve elde edilen bulguların sigara kullanımıyla ilişkili olup olmadığııın araştırılmasıdır.

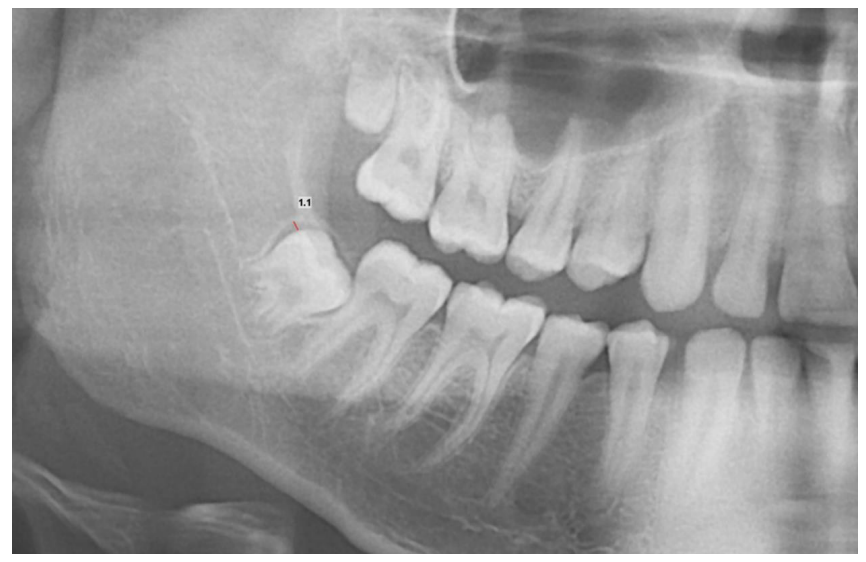

Resim 1. Çalışmaya dahil edilen hastalardan alınan panoramik radyografide yapılan dijital ölçüm.

\section{Materyal-Method}

$\mathrm{Bu}$ çalışma Süleyman Demirel Üniversitesi Diş Hekimliği Fakültesi Ağız Diş Çene Cerrahisi Anabilim Dalı'nda gerçekleştirildi. Çalışma için 08.05.2013 tarihinde, 125 sayı ile Süleyman Demirel Üniversitesi Tıp Fakültesi Klinik Araştırmalar Etik Kurulu'ndan onay alındı. Proje Süleyman Demirel Üniversitesi Bilimsel Araştırma Projeleri Koordinasyon Birimi Destekleme Protokolü tarafından, 28.05.2013 tarihli karar ve 3608-D2-13 proje numaras1 ile desteklendi.

Çalışmaya, Süleyman Demirel Üniversitesi Diş Hekimliği
Fakültesi Ağız Diş Çene Cerrahisi Anabilim Dalı kliniğine, tam gömük alt yirmi yaş dişi çekimi için başvuran hastalar dahil edildi. Çalışmaya, 18 yaşından büyük, sistemik olarak sağlıklı, son bir ay içerisinde analjezik veya antibiyotik kullanmamış, klinik olarak asemptomatik tam gömük alt yirmi yaş dişi olan 50 sigara içen ve 50 sigara içmeyen olmak üzere toplam 100 hasta dahil edildi. Hastaların sosyodemografik bilgileri, sigara kullanma durumları kaydedildi.

Çalışmaya dahil olan tüm hastaların işlem öncesinde panoramik radyografileri alındı. Radyografiler Planmeca, ProMax (Planmeca Oy, Helsinki, Finlandiya) X-ray cihazı ile elde edildi ve Planmeca Romexis (Planmeca Oy, Helsinki, Finlandiya) yazılımı aracılığıyla dijital ortama aktarıldı. Programdaki araçlar kullanılarak çalışmaya dahil edilen gömük alt yirmi yaş dişlerinin perikoronal aralıkları, en geniş noktaları baz alınarak dijital olarak ölçüldü. Perikoronal aralığı 2,5 mm'den geniş olan dişler çalışma dişı bırakıldı (Resim 1).

Çalışmaya dahil edilen tüm hastaların yaşı, cinsiyeti, sigara kullanma durumları kaydedildi. Sigara kullanan hastaların, sigara kullanma süreleri yıl olarak ve günde içtikleri sigara miktarı kaydedildi. Bir günde tüketilen paket sayısı ile sigara kullanılan yıl sayısı çarpılarak paket yılı hesaplandı.

Çalışma kriterlerine uyan hastalara, yapılacak işlemler ve olası riskleri anlatıldıktan sonra çalışma hakkında bilgi verildi. Çalışmaya dahil olmayı kabul eden hastalara "Aydınlatılmış onam formu" imzalatılarak onayları alındı.

Araştırma kapsamında tüm cerrahi işlemler Süleyman Demirel Üniversitesi Diş Hekimliği Fakültesi Ağız Diş Çene Cerrahisi Anabilim Dalı ameliyathanesinde, lokal anestezi altında, asepsi-antisepsi koşulları sağlanarak gerçekleştirildi. Perikoronal folikül tek parça halinde ve zedelenmeden çıkarılmaya çalışıldı. Foliküller immunohistokimyasal boyama yapılıncaya kadar \%10'luk formaldehit içinde $+4^{\circ} \mathrm{C}$ 'de muhafaza edildi.

Elde edilmiş olan kesitlerin biri Ki67 proteinine karşı geliştirilmiş monoklonal antikor (NCL-L-Ki67-MM1, Novocastra) ile, biri de p53 proteinine karş1 geliştirilmiş monoklonal antikor (NCL-L-p53-DO7, Novocastra) ile boyand1. p53 ve Ki-67 proteinlerinin immünhistokimyasal boyamalarında kullanılan antikorlar üretici firmanın önerdiği şekilde taze olarak hazırlandi.

İmmunohistokimyasal boyanmanın değerlendirilmesinde iki faktör göz önünde bulunduruldu. İlk olarak, hücre çekirdeği boyanan hücre sayısı skorland1. Daha sonra ise hücre çekirdeklerinin boyanma yoğunluğu skorlandı.

Boyanan hücre sayısına göre

0 puan : boyanma yok

1 puan : \%1'den az boyanma var

2 puan : \%1-10 arası boyanma var

3 puan : \%11-33 arası boyanma var

4 puan : \%34-66 arası boyanma var

5 puan : \%67'den fazla boyanma var 
Boyanma yoğunluğuna göre

0 puan : boyanma yok

1 puan : zayıf boyanma var

2 puan : orta derecede boyanma var

3 puan : yoğun boyanma var

şeklinde skorlandı ve iki skorun toplamı, incelenen örneğin skoru olarak alındı. Skorlama işleminden sonra toplam skoru 4'ten küçük olan örnekler "negatif", 4'ten büyük olanlar ise “pozitif” olarak değerlendirildi (8).

\section{Bulgular}

Çalışmaya katılan hastaların yaş ortalaması $22,85 \pm 5,85$ 'ti. Sigara kullanmayan kontrol grubunun yaş ortalaması $21,36 \pm 5,12$, sigara kullanan çalışma grubunun yaş ortalaması ise $24,34 \pm 6,20$ olarak bulunmuştur. Kadınların yaş ortalaması $23,21 \pm 6,89$, erkeklerin ise 22,36 $\pm 4,04$ 'tür (Tablo 1).

Tablo 1. Çalışmaya dahil edilen hastaların sigara kullanma durumu ve cinsyiyete göre yaş ortalamaları dağılımı.

\begin{tabular}{lccc}
\hline & \multicolumn{2}{c}{ Sigara kullanma durumu } & \multirow{2}{*}{ Yaş ortalaması } \\
\cline { 2 - 3 } & \multicolumn{1}{c}{+} & \\
\cline { 2 - 3 } Kadın & $26,89 \pm 8,23$ & $21,55 \pm 5,55$ & \\
\multirow{2}{*}{ Erkek } & $22,91 \pm 4,21 \pm 6,89$ \\
Yaş ortalaması & $24,34 \pm 6,20$ & $21,36 \pm 5,12$ & $22,85 \pm 5,85$ \\
\hline
\end{tabular}

Çalışmaya dahil edilen hastaların \%58'i kadın, \%42'si erkektir. Sigara içen hastaların \%36'sı kadın, \%64'ü erkek hastadan oluşmaktadır. Sigara kullanmayan hastaların ise \%80'i kadın, \%20'si erkek hastadan oluşmaktadır (Tablo 2).

Tablo 2. Cinsiyetlere göre sigara kullanım durumu dağılımı.

\begin{tabular}{lcccc}
\hline \multicolumn{5}{c}{ Cinsiyet } \\
\hline \multirow{3}{*}{ Sigara } & - & $40(40)$ & $10(10)$ & $50(50)$ \\
\cline { 2 - 5 } & + & $18(18)$ & $32(32)$ & $50(50)$ \\
\multirow{2}{*}{ Toplam } & & $58(58)$ & $42(42)$ & $100(100)$ \\
\hline
\end{tabular}

Çalışmaya dahil edilen hastaların sigara kullanma alışkanlıkları incelendiğinde, sigara kullanımında en kısa süre 7 ay, en uzun süre 33 y1l olarak tespit edildi. Ortalama sigara kullanma

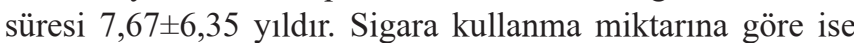
en az sigara kullanan hasta ayda 1-2 adet sigara kullandığını belirtirken, en çok sigara kullanan hasta günde 30 adet sigara kullandığını belirtmiştir. Çalışma grubunun ortalama günde kullandığ 1 sigara adedi $12,49 \pm 7,48$ bulunmuștur. Günlük tüketilen sigaranın paket cinsinden miktarı ile toplamda sigara kullanılan sürenin yıl olarak çarpımı ile elde edilen "paket/ yıl" değerleri ise en düşük 0,006, en yüksek 25 bulunmuştur.

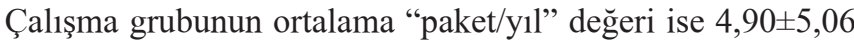

olarak bulunmustur.

Çalışmaya katılan hastaların sosyodemografik bilgileri, diş retansiyonu, dişin pozisyonu Tablo 3'de verilmiştir.

Tablo 3. Çalışmaya katılan hastaların sosyo-demografik bilgileri.

\section{Sayı (\%)}

\section{Cinsiyet}

Kadın

Erkek

Sigara kullanımı

$\begin{array}{ll}\text { Evet } & 50(50) \\ \text { Hayır } & 50(50)\end{array}$

Kemik retansiyonu

\begin{tabular}{lcc}
\hline Tam & $70(70)$ \\
Yarım & $30(30)$ \\
\hline Diş pozisyonu & \\
\hline Distoanguler & $2 \quad(2)$ \\
Vertikal & $55(55)$ \\
Mezioanguler & $17(17)$ \\
Horizontal & $26(26)$
\end{tabular}

Kontrol ve çalışma grubunda yapılan immunohistokimyasal analizlerde, p53 ve Ki-67 proteinlerinin boyanma skorları değerlendirilmiş ve doku örneklerinin boyanma skorları 4'den düşük bulunduğu için "negatif” olarak rapor edilmiştir (Resim $2 \mathrm{a}$ ve b). Bu verilere istatistiksel analiz uygulanamamıştır.

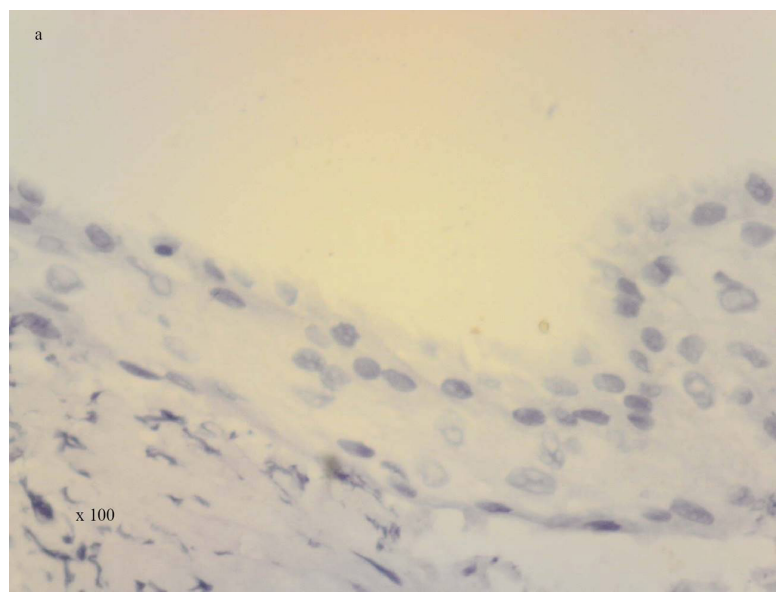

Resim 2a. Örneklerin immünohistokimyasal boyanma sonuçları, Ki-67 boyamas1, x100 büyütme. 


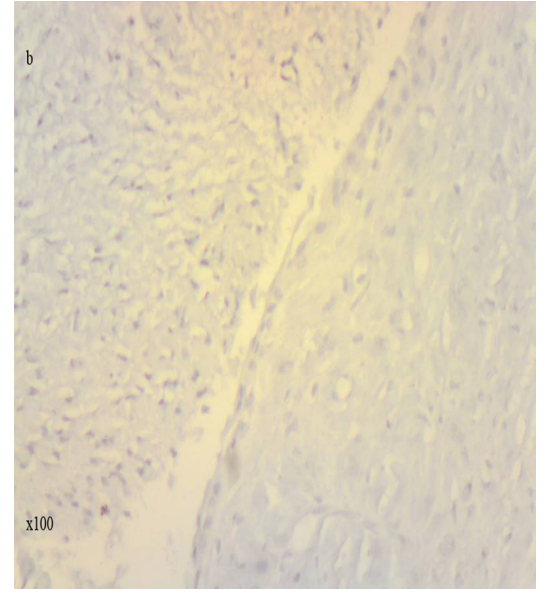

Resim 2b. Örneklerin immünohistokimyasal boyanma sonuçları, p53 boyamas1, x100 büyütme.

\section{Tartıșma}

Asemptomatik gömük dişlerin proflaktik çekimi hakkında henüz görüș birliğine varılamamıștır. Proflaktik çekimi savunan araştırmacılar bu dişlerin her zaman patolojik dönüşüm riski taşıdıklarını ve ilerleyen yaşlarda postoperatif komplikasyonlar ve tedavinin daha zor tolere edilebileceğini öne sürmektedirler (9).

Literatürde, panoramik radyografide perikoronal radyolusensinin, 2,5-3 mm'den geniş olduğu dişlerin şüpheli olarak değerlendirilmesi gerektiği belirtilmiştir (10). Ancak yapılan çalışmalarda perikoronal radyolusensinin $2,5 \mathrm{~mm}$ 'den daha az olduğu ve klinik olarak asemptomatik olan dişlerin perikoronal foliküllerinde de histopatolojik değişikliklerin görülebileceği rapor edilmiştir $(11,12)$.

Odontojenik patolojilerin etyolojisinde, epitel artıklarının proliferasyonunun rol oynadığ düşünülmektedir. Odontojenik keratokistik tümör, dentigeröz kist, dental folikül ve oral mukoza üzerinde yapılan çalışmada, odontojenik keratokistik tümörde dentigeröz kistten ve dentigeröz kistte dental folikül ve oral mukozadan daha yüksek oranda Ki-67 tespit edilmiş ve Ki-67 boyanan hücreler sağlıklı dokuda bazal tabakada sınırlı iken displazik ve kistik dönüşüm görülen olgularda boyanmanın yüzeyel tabakalara da uzandığı görülmüştür $(13,14)$.

Ki-67 üzerine yapılan çalışmalar, bu proteinin bilinen en önemli özelliğinin sadece çoğalan hücrelerin çekirdeklerinde (G1, S, G2 ve M evreleri) bulunurken dinlenme fazındaki hücre çekirdeklerinde (G0) görülmemeleri olduğunu göstermiştir $(15,16)$. Ki-67 proteini üzerine yapılan çalışmalar sonucunda, bu proteinin belirli bir hücre popülasyonunun "büyüme fraksiyonunu" belirlemede kullanılabileceği gösterilmiştir (17).

p53, bulunan ilk tümör baskılayıcı genlerden biridir. p53 proteini normal sağlıklı dokularda çok az miktarda bulunur ve yarı ömrü çok kısa olduğu için rutin immunohistokimyasal yöntemlerle tespit edilemez (18-21). Ancak normal hücre döngüsünün ilerleyişini bozan veya hücrenin genomunda bir mutasyona neden olabilecek herhangi bir hücresel stres varlığında p53 proteini çeşitli yolaklarla stabilize olarak hücrelerde daha uzun süre kalır (7). Çeşitli lezyonlarda immunohistokimyasal yöntemlerle p53 proteininin ekspresyonunun araştırıldığı çalışmalarda, normal sağlıklı dokularda p53 proteini gözlenmezken ya da sadece hücre çoğalmasının olduğu bazal tabakada gözlenirken, farklı evrelerdeki kanser dokularında ve premalign lezyonlarda p53 proteininin ekspresyonunun arttığ 1 ve suprabazal tabakalara da yayıldığ 1 gösterilmiștir $(14,20,22-24)$. Premalign ve malign lezyonlarda p53'ün yüksek oranda ekspresyonunun izlenmesi, bu proteinler hakkında iki görüşü öne çıkarmıştır. Bazı çalışmacılar, p53 proteininin tümör baskılayıcı özelliğinden dolayı malign ve premalign lezyonların etyolojisinde rol oynayan DNA hasarlarının tamiri için hücre döngüsünü durdurmak veya hasarlı DNA'ya sahip hücreleri apoptoza yönlendirmek, böylelikle tümör hücrelerinin aşırı çoğalmasını ve ilerlemesini engellemek amacıyla transkripsiyonunun arttığını iddia etmektedirler $(25,26)$. Bu süreçte p53'ün yıkılması engellenmekte ve proteinin yarı ömrü 48 saate kadar uzayabilmektedir $(18,27,21)$ İkinci bir görüşe göre ise TP53 geninde meydana gelen bir mutasyon nedeniyle mutant ve yarı ömrü daha uzun olan (yaklaşık 9 saat) bir protein sentezlenmektedir ve dokularda tespit edilebilen protein, mutant p53 proteinidir $(18,21,28,29)$.

Radyografik olarak sağlıklı, asemptomatik tam gömük alt yirmi yaş dişlerinin çekimi ile ilgili yapılan çalışmalarda, perikoronal dokularin histopatolojik inceleme ve immunohistokimyasal boyamaları yaygın olarak kullanılan bir metotdur. Baas et al. (30) tarafindan hatalı pozitif sonuç verme ihtimalinin bulunduğu rapor edilmesine rağmen özellikle sağlıklı dokularda, düşük seviyelerdeki p53 proteininin boyanmasını sağlamak için antijen retrieval yöntemi ve sinyal amplifikasyon yöntemi ile antikorların hassasiyetinin arttırılması yaygın olarak kullanılan bir yöntemdir. Ancak bu proteinlerin farklı lezyonlarda ve kanser türlerinde ekspresyonunun artmasının, proteinlerin stabilizasyonunun artmasından mi kaynaklandığ 1 yoksa bu proteinleri sentezleyen gen bölgelerinde bir mutasyon sonucu yarı ömrü daha uzun proteinlerin sentezlenmesinden mi kaynaklandığı tam olarak açıklanamamıştır. Genel görüş lezyonların şiddeti arttıkça özellikle p53 proteininin boyanma yoğunluğu ve dağılımının değiştiği yönündedir. Ayrıca p53 proteininin ekspresyonundaki artışla, TP53 geninde mutasyon görülme sıklığı arasında korelasyon bulunmuştur (31).

Bizim çalışmamızda, gömük alt yirmi yaş dişlerinin folikül hücrelerinin büyüme fraksiyonunu belirlemek için dokularda Ki-67 boyanması incelenmiştir. Ayrıca sigara içen ve içmeyen bireylerin dokularının hücre çoğalma indeksi arasında fark olup olmadığı araştırılmıştır. Sigaranın hücreler üzerindeki genotoksik etkilerinin belirlenmesi için hücre genomunun koruyucusu olan p53 proteininin ekspresyonu immunohistokimyasal yöntemlerle incelenmiştir.

Yapılan çalışmada sigara içen ve içmeyen bireylerde, radyografik ve klinik olarak sağlıklı tam gömük alt yirmi yaş dişlerinin perikoronal foliküllerinde yapılan immunohistokimyasal boyama işleminde, Ki-67 boyanma sonuçları "negatif" olarak bulunmuştur. Bu sonuçlar daha önce Toptaş et al. (32), Cabbar et al. (13), Edamatsu et 
al. (33) 'ın yaptıkları çalışmalarının sonuçlarından farklı bulunmuştur. Edematsu et al. (33)'ın çalışmasında, Ki-67 ekspresyonunun folikül epitelinin morfolojik özelliklerinin farklılığından etkilenebileceği belirtilmiştir. Çalışmasında, proliferatif rete çıkıntıları bulunan folikül epitellerinde Ki67 indeksinin, indirgenmiş mine epiteli ve çok katlı yassı epitel içeren foliküllerdekinden daha yüksek olduğunu rapor etmiştir. Benzer şekilde Cabbar et al. (13) da çalışmalarında inceledikleri foliküllerde, folikül epitelindeki histolojik değişikliklerin Ki-67 indeksini etkilediğini rapor etmişlerdir. Toptaş et al. (32) ise çalışmasında Ki-67 indeksindeki farklılığı bireylerin sigara kullanımına bağlamıştır.

Bizim çalışmamızın Ki-67 ekspresyonu ile ilgili sonuçları, Saraçoğlu et al. (34) çalışmasıyla uyumlu bulunmuştur. Saraçoğlu et al. (34) çalışmalarında odontojenik epitel artıklarında Ki-67 boyanmasının bulunmamasını, bu hücrelerin dinlenme fazında olmasına bağlamıștır. Oliveira et al. (35) dental folikülün morfolojik yapısını inceledikleri çalışmalarında \%23 oranında epitelin bulunmadığını, $\% 63$ oranında indirgenmiş mine epitelinin bulunduğunu ve $\% 14$ oranında çok katlı yassı epitel bulunduğunu rapor etmişlerdir. Ayrıca diş gelişimi ilerledikçe folikül epitelindeki aktivitenin azaldığını belirtmişlerdir. Bunu da folikülün zamanla olgunlaşmasına bağlamışlardır. Villalba et al. (10) çalışmasında enflamasyon gözlenen folikülleri çalışma dışı bırakmış ve sonuçta diğer çalışmacılardan daha düşük Ki-67 indeksi rapor etmiştir. Daha önceki çalışmalarda yüksek Ki67 indeksi bulunmasını bu foliküllerde enflamasyon varlığına bağlamıştır. Bizim çalışmamızda Ki-67 boyanmasının gözlenmemesinin nedeni folikülde epitel izlenmemesi veya epitel hücrelerinin dinlenme fazında olması olabileceği düşünülmektedir. Ayrıca klinik ve radyografik olarak asemptomatik dişlerin seçilmesi nedeniyle, her ne kadar histopatolojik incelemelerle teyit edilmemiş olsa da, folikül örneklerinde enflamasyon olmaması da Ki-67 ekspresyonunun izlenmemesine sebep olarak gösterilebilir.

Bizim çalışmamızda yapılan immunohistokimyasal boyamalarda dental foliküllerde p53 boyanma sonuçları “negatif” olarak bulunmuştur. Bu sonuçlar Toptaş et al. (32)'ın. çalışmasının sonuçlarıyla uyumluluk göstermemektedir. Toptaş et al. (32) çalışmalarında sigara içen bireylerde daha yoğun olmak üzere sigara içmeyen bireylerde de p53 ekspresyonu gözlendiğini belirtmiştir. Sigara içen bireylerde ekspresyonun daha yoğun olmasını ise sigaranın kanserojen etkisi dolayısıyla TP53 geninde meydana gelmiş olabilecek mutasyonlara bağlamıştır. Kaur et al. (36) ve Field et al. (37) normal sağlıklı mukozada, oral malign lezyonlu bölgenin karşıt tarafında yer alan sağlıklı mukozada, oral malign lezyon çevresindeki sağlıklı mukozada ve nonmalign lezyonlarda p53 boyanmasının izlenmediğini bununla beraber displazik lezyonlarda ve oral yassı hücreli karsinomda aşırı ekspresyonunun izlendiğini rapor etmişlerdir. Ayrıca p53'ün aşırı ekspresyonunun tütün ürünlerinin kullanımıyla ilişkili olduğu belirtilmiștir. Ralhan et al. (38) tütün ürünü kullanan, premalign lezyon ve yassı hücreli karsinom teşhisi konmuş hastalarda TP53 mutasyonu ve p53 ekspresyonunu araştırmışlar ve missense mutasyon görülen vakalarda p53 ekspresyonu izlenirken, nonsense mutasyon izlenen vakalarda p53 boyanması izlenmediğini rapor etmişlerdir.

Yapılan çalışmada elde edilen p53 ekspresyonu sonuçları Matsumoto et al. (39) ve Kaur et al. (37)'nın çalışmalarının sonuçları ile uyumludur. Matsumoto et al. (39) indirgenmiş epitel ve çok katlı yassı epitel içeren dental foliküllerde p53 tespit edilmediğini rapor etmiştir. Semenzati et al. (4) sigara dumanına maruz birakılan ratlarda Ki-67 ekspresyonu izlenirken, p53 ekspresyonu izlenmediğini rapor etmişlerdir. Araştırmacılar, sigaranın oluşturduğu hasar nedeniyle dokularda proliferasyonun arttığını ve bu nedenle Ki-67 ekspresyonu izlendiğini ancak deney süresinin k1sa olması nedeniyle neoplastik dönüşümün başlamadığını ve bu nedenle p53 ekspresyonunun gözlenmemiş olabileceğini iddia etmişlerdir. Bizim çalışmamızda, Ki-67 skorlarına bakarak, örneklerde sigaraya bağlı hücre proliferasyonunda artış meydana gelmediği söylenebilir. Örneklerin p53 skorlarının " 0 " bulunmasının nedeni olarak, hücrelerin proliferasyon hızında artış olmaması, sigaranın kanserojen etkilerine bağlı TP53 geninde yarı ömrü uzun mutant p53 proteini sentezlenmesine neden olacak bir mutasyon meydana gelmemiş olması ve sağlıklı p53 proteininin yarı ömrünün çok kısa olması gösterilebilir. p53 ve Ki-67 proteinlerinin ekspresyonlarını değerlendirmek amacıyla, asemptomatik dişlerle beraber klinik ve radyografik olarak semptom vermiş dişlerin de dahil edildiği ve histopatolojik incelemelerin de yapıldığı daha kapsamlı bir çalışma yapılabilir.

Yapılan çalışmada, p53 ve Ki-67 proteinlerinin immünhistokimyasal boyama skorlarının güvenirliliği amacıyla, üretici firma tarafından önerildiği şekilde taze olarak hazırlanan p53 ve Ki-67 monoklonal antikorları kontrol dokuları ile çalışılmış ve boyanma tespit edildikten sonra örneklerin boyamaları otomatik olarak ve skorlamaları manuel olarak yapılmıştır.

Asemptomatik tam gömük alt yirmi yaş dişlerin proflaktik çekimi konusunda henüz görüş birliğine varılabilmiş değildir. $\mathrm{Bu}$ dişlerin perikoronal dokularında yapılan histopatolojik incelemeler sonucunda patolojik değişiklikler meydana gelebileceği gösterilmiştir. Bu çalışmalarda en sık rastlanan patoloji olan kist prevalansı \%2-50 arasında bulunmuştur (3, 11). Çalışmalar arasındaki farkın ise kist teşhisi kriterlerindeki farklılıktan kaynaklandığ1 düşünülmektedir. Bu dişlerdeki malign tümör prevalansı ise $\% 1$ 'den düşük bulunmuştur $(3,40)$. p53 ve Ki-67 ile yapılan immunohistokimyasal çalışmalarda da birbiriyle çelişen sonuçlar elde edilmiştir. $\mathrm{Bu}$ farklı sonuçların hem kullanılan antikorun çeşidine, hem de dokuların morfolojik özelliklerine bağlı olduğu öne sürülmüştür $(10,13,32,33,36,37,39)$. p53 boyanmas1 tespit edilen çalışmalarda dokuların histolojik incelemelerinde displazi, metaplazi ve enflamasyon izlenmesi bu dişlerin gerçekte asemptomatik olmadığını, patolojik dönüşümün başladığını ancak klinik ve radyografik olarak bulgu vermediğini düşündürmektedir. p53 boyanmasının elde edildiği çalışmalarda öne sürülen bir diğer hipotez, p53'ün sigara gibi kanserojen maddelere maruziyet sonucu mutasyona uğramış olması nedeniyle dokularda birikmiş olabileceğidir. 
Çalışmamızda, yapılan çalışmanın limitasyonları içerisinde, sigara kullanımının patolojik dönüşüm riskini arttırdığına dair bulgulara rastlanmamıştır. Daha geniş serilerde yapılacak ileri çalışmalara ihtiyaç vardır. Asemptomatik tam gömük alt yirmi yaş dişlerinin çekim kararını verirken, dişin klinik ve radyografik değerlendirmesi dikkatli bir şekilde yapılmalıdır. Hasta, sosyokültürel durumu da dikkate alınarak, cerrahi çekimin komplikasyonları hakkında detaylı bir şekilde bilgilendirilmeli, ve karar hasta ile beraber verilmelidir.

\section{Kaynakça}

1. Adeyemo WL. Do pathologies associated with impacted lower third molars justify prophylactic removal? A critical review of the literature. Oral Surg Oral Med Oral Pathol Oral Radiol Endod 2006;102(4):448-52.

2. Regezi JA, Sciubba JJ, Jordan RC. Oral pathology: clinical pathologic correlations: Elsevier Health Sciences; 2012.

3. Ozarslan SK, Baykul T, Basak K, Kocer G, Tuzum S. Detection of epidermal growth factor receptor intensity in asymptomatic fully impacted lower third molar follicles of smoking and nonsmoking patients. J Craniofac Surg 2013;24(2):435-8.

4. de Oliveira Semenzati G, de Souza Salgado B, Rocha NS, Michelin Matheus SM, de Carvalho LR, Garcia Martins RH. Histological and immunohistochemical study of the expression of p53 and ki-67 proteins in the mucosa of the tongue, pharynx and larynx of rats exposed to cigarette smoke. Inhalation Toxicology 2012;24(11):723-31.

5. Prasad SHVR. Expression of p53 protein and ki-67 antigen in oral premalignant leions an oral squamous cell carcinomas: An immunohistochemical study. Natil J Maxillofac Surg 2011;2(1):38-46.

6. Brown D, Gatter K. Ki67 protein: the immaculate deception? Histopathology 2002;40(1):2-11.

7. Bourdon J-C. p53 Family isoforms. Curr Pharm Biotechnol 2007;8(6):332.

8. Meert AP, Feoli F, Martin B, Verdebout JM, Mascaux C, Verhest A, et al. Ki67 expression in bronchial preneoplastic lesions and carcinoma in situ defined according to the new 1999 WHO/IASLC criteria: a preliminary study. Histopathology 2004;44(1):47-53.

9. Chuang SK, Perrott DH, Susarla SM, Dodson TB. Age as a risk factor for third molar surgery complications. J Oral Maxillofac Surg 2007;65(9):1685-92.

10. Villalba L, Stolbizer F, Blasco F, Mauriño NR, Piloni MJ, Keszler A. Pericoronal follicles of asymptomatic impacted teeth: a radiographic, histomorphologic, and immunohistochemical study. Int J Dent 2012; Article ID 935310, 6 pages.

11. Saravana GH, Subhashraj K. Cystic changes in dental follicle associated with radiographically normal impacted mandibular third molar. $\mathrm{Br} \mathrm{J}$ Oral Maxillofac Surg 2008;46(7):552-3.

12. Wali GG, Sridhar V, Shyla HN. A study on dentigerous cystic changes with radiographically normal impacted mandibular third molars. J Maxillofac Oral Surg 2012;11(4):458-65.

13. Cabbar F, Guler N, Comunoglu N, Sencift K, Cologlu S. Determination of potential cellular proliferation in the odontogenic epithelia of the dental follicle of the asymptomatic impacted third molars. J Oral Maxillofac Surg 2008;66(10):2004-11.

14. Takeda KS, Hirayama Y, Hirano M, Tanuma JI, Semba I. Immunohistological evaluation of Ki-67, p63, CK19 and p53 expression in oral epithelial dysplasias. J Oral Pathol Med 2006;35(6):369-75.

15. Gerdes J, Lemke H, Baisch H, Wacker H-H, Schwab U, Stein H. Cell cycle analysis of a cell proliferation-associated human nuclear antigen defined by the monoclonal antibody Ki-67. J Immunol 1984;133(4):1710-5.

16. MacCallum DE, Hall PA. The location of pKi67 in the outer dense fibrillary compartment of the nucleolus points to a role in ribosome biogenesis during the cell division cycle. $\mathrm{J}$ Pathol 2000;190(5):537-44.

17. Bullwinkel J, Baron-Lühr B, Lüdemann A, Wohlenberg C, Gerdes J, Scholzen T. Ki-67 protein is associated with ribosomal RNA transcription in quiescent and proliferating cells. J Cell Physiol 2006;206(3):624-35.

18. Nylander K, Dabelsteen E, Hall PA. The p53 molecule and its prognostic role in squamous cell carcinomas of the head and neck. J Oral Pathol Med 2000;29(9):413-25.

19. Ebrahimi M, Boldrup L, Coates PJ, Wahlin Y-B, Bourdon $\mathrm{J}-\mathrm{C}$, Nylander K. Expression of novel p53 isoforms in oral lichen planus. Oral Oncol 2008;44(2):156-61.

20. Nasser W, Flechtenmacher C, Holzinger D, Hofele C, Bosch FX. Aberrant expression of p53, p16INK4a and Ki-67 as basic biomarker for malignant progression of oral leukoplakias. J Oral Pathol Med 2011;40(8):629-35.

21. Slade N, Moll U. Mutational Analysis of p53 in Human Tumors. In: Deb S, Deb S, editors. p53 Protocols. Methods in Molecular Biology. 234: Springer New York; 2003. p. 23143.

22. Shetty S, Krishnapillai R, Prabhu S. Assessment and comparison of p53 and p63 expression in oral epithelial dysplasia and squamous cell carcinoma. SRM J Res Dent Sci 2014;5(3):149.

23. Kumar P, Kane S, Rathod GP. Coexpression of p53 and $\mathrm{Ki} 67$ and lack of c-erbB2 expression in oral leukoplakias in India. Braz Oral Res 2012;26(3):228-34.

24. Baweja P, Monappa V, Krishnanand G. P53 Immunohistochemical Staining Patterns in Benign, Premalignant and Malignant Lesions of the Oral Cavity: A Study of 68 Cases. J Interdiscip Histopathol 2013;1(3):11320.

25. Levine AJ. p53, the Cellular Gatekeeper for Growth and Division. Cell 1997;88(3):323-31.

26. Lane DP. Cancer. p53, guardian of the genome. Nature 1992;358(6381):15-6.

27. Prives C, Hall PA. The p53 pathway. J Pathol 
1999;187(1):112-26.

28. Kubbutat MHG, Vousden KH. Keeping an old friend under control: regulation of p53 stability. Mol Med Today 1998;4(6):250-6.

29. Slootweg PJ. p53 protein and Ki-67 reactivity in epithelial odontogenic lesions. An immunohistochemical study. J Oral Pathol Med 1995;24(9):393-7.

30. Baas IO, Van Den Berg FM, Mulder JWR, Clement MJ, Slebos RJ, Hamilton SR, et al. Potential False-Positive Results With Antigen Enhancement For Immunohistochemistry of the p53 Gene Product in Colorectal Neoplasms. J Pathol 1996;178(3):264-7.

31. Takami H, Yoshida A, Fukushima S, Arita H, Matsushita Y, Nakamura T, et al. Revisiting TP53 mutations and immunohistochemistry-a comparative study in 157 diffuse gliomas. Brain Pathol 2015;25(3):256-65.

32. Toptaş O, Baykul T, Başak K. Does smoking affect the Ki67 and p53 expressions in asymptomatic fully impacted lower third molar follicles? J Oral Maxillofac Surg 2015;73(5):819-26.

33. Edamatsu M, Kumamoto H, Ooya K, Echigo S. Apoptosisrelated factors in the epithelial components of dental follicles and dentigerous cysts associated with impacted third molars of the mandible. Oral Surg Oral Med Oral Pathol Oral Radiol Endod 2005;99(1):17-23.

34. Saracoglu U, Kurt B, Gunhan O, Guven O. MIB-1 expression in odontogenic epithelial rests, epithelium of healthy oral mucosa and epithelium of selected odontogenic cysts. An immunohistochemical study. Int J Oral Maxillofac Surg 2005;34(4):432-5.

35. de Oliveira DM, de Souza Andrade ES, Da Silveira M, Camargo IB. Correlation of the radiographic and morphological features of the dental follicle of third molars with incomplete root formation. Int J Med Sci 2008;5(1):3640.

36. Field J, Spandidos D, Malliri A, Gosney J, Yiagnisis M, Stell P. Elevated P53 expression correlates with a history of heavy smoking in squamous cell carcinoma of the head and neck. Br J Cancer 1991;64(3):573.

37. Kaur J, Srivastava A, Ralhan R. Overexpression of p53 protein in betel-and tobacco-related human oral dysplasia and squamous-cell carcinoma in India. Int $\mathrm{J}$ Cancer 1994;58(3):340-5.

38. Ralhan R, Agarwal S, Nath N, Mathur M, Wasylyk B, Srivastava A. Correlation between p53 gene mutations and circulating antibodies in betel-and tobacco-consuming North Indian population. Oral Oncol 2001;37(3):243-50.

39. Matsumoto MA, Filho HN, Jorge FM, Salvadori DM, Marques ME, Ribeiro DA. Expression of cell cycle regulatory proteins in epithelial components of dental follicles. J Mol Histol 2006;37(3-4):127-31.

40. Curran AE, Damm DD, Drummond JF. Pathologically significant pericoronal lesions in adults: Histopathologic evaluation. J Oral Maxillofac Surg 2002;60(6):613-7. 